\title{
Letter to a Young Scientist
}

\author{
By Jeffrey K. McKee, PhD
}

The beauty of a scientific career is that one never loses the wonder and imagination of a child. Certainly one's youthful views are replaced by adult circumspection, rigorous precision, and dutiful respect of all those who also commit their lives to science. Yet the amazement never subsides, and a healthy imagination is essential for probing the complex realities of the natural world.

I leaned toward science from an early age. Dinosaur fossils from afar fascinated me as young child, as did arrowheads, left behind by ancient native Americans. The stone artifacts could be readily found in the up-turned soil of farm fields around my native Ohio. To me they were ancient treasures, more valuable than gold. Our past was as good of a path of exploration as any, and a key to understanding our present.

When I was about thirteen years old I watched a National Geographic special on one of the four television channels we then received. The show was about a paleontologist named 'Louis Leakey'. Having read books about dinosaurs, I was still fascinated by fossils of all kinds. Louis Leakey, and his archeologist wife Mary, had been working in the African country of Tanzania, along the dry dessert edges of Olduvai Gorge. The gorge had been formed by geological tensions, millions of years ago, that literally tore the African continent apart, leaving what is known as the 'Great Rift Valley'.

What became exposed at Olduvai Gorge was a treasure trove of our past. Millions of years of sediments that had accumulated were left in cross-section. The Leakey family scoured these sediments, finding numerous primitive stone tools. We now call these ancient artifacts the 'Oldowan tool industry', the earliest precursors to the stone tools I found on Ohio farms. The Leakey family eventually found fossil bones of our ancestral lineage as well. That led to the National Geographic special on TV, during which I was en- thralled as I watched Louis Leakey walk down the side of Olduvai Gorge. The narrator said, "Now Leakey starts down the gorge, beginning a walk backwards into time. An average of 6000 years is traversed with each foot he descends. With each step, the earth's majestic history rolls back." I was hooked. That was going to be what I would do.

It seemed far-fetched for a boy from Ohio to aspire to discovering fossils of our evolutionary ancestors in distant lands. At the time, Ohio schools did not teach evolutionary biology, and human evolution was seen by most around the state as a fantasy to be scorned. But like so many young scientists, my curiosity led me to venture beyond the limitations of school curricula and absorb what I could out of books and science magazines.

There were only minor obstacles in my quest for learning. Little of what I sought was in our libraries and book stores. I recall going to a local book store to put in an order for a book by Louis Leakey (195) entitled Adam's Ancestors: The Evolution of Man and His Culture. The elderly lady taking my order looked down at me, her stern eyes peering at me from over her glasses, and said slowly: "Are you sure you want to order this book?" "Yes, please," I replied with a smile. A week later I had the book in my hands, and even the elderly lady allowed herself a faint smile as I paid for it.

I didn't know it at the time, but Ohio had some important affiliations with African paleoanthropology, the science of our fossil ancestors. Raymond Dart was a traveling scholar from Australia, who spent some time studying anatomy at the University of Cincinnati in 1921 (Wheelhouse and Smithford, 2001). He even met his future wife there, who along with others would follow him to South Africa. There, in Johannesburg, Dart became chair of the Department of Anatomy at the University of the Witwatersrand. 
In 1924 he received a box of fossils from a limestone quarry at a place called 'Taung', a small South African village at the southeastern margin of the Kalahari desert.

Dart's box from Taung contained many interesting fossils. But the key was what we call an 'endocast'. This is a cast of the inside of a skull. What had happened is that some 2.8 million years ago, a skull had filled with sediment inside a cave, and the sandstone solidified, leaving the impression that a brain leaves on the inside of a skull Quarry operations at Taung blasted through the filled-in cave, leaving most of the skull behind, but keeping the endocast intact.

Dart, through his studies in Australia, as well as St. Louis, Missouri, and Cincinnati, Ohio, was an expert on the anatomy of the mammalian and human brain. He recognized that the brain endocast from Taung had the peculiar qualities of some creature that had erect posture and must have walked on two legs. He gave the fossil the scientific name 'Australopithecus africanus' (Dart, 1925), and it became the first solid evidence that a prediction from Charles Darwin was true - that human ancestors first originated in Africa (Darwin 1871).

What is peculiar is that Raymond Dart did not go to Taung until 1948, when he finally joined an American expedition of scholars, including Dr. George B. Barbour, a geologist from the University of Cincinnati. The next year, Barbour presented his South African research findings in the presidential address to The Ohio Academy of Science at Dennison University in Granville, Ohio (Figure 1). I eventually made to Africa, and to Taung, as well, where I led research and excavations from 1986 to 1993 . My youthful dream had come true, and along with me at the fossil site was a scientific paper I referenced on numerous occasions, published in this very journal (Barbour 1949).

Ohio now has more key connections to African paleoanthropology. While I was an undergraduate anthropology student as at Miami University, exciting word came out of discoveries of Australopithecus fossils in East Africa. The team had been led by Donald C. Johanson, from the Cleveland Museum of Natural History. This became the species best known for the 'Lucy' skeleton. Indeed, the species name, Australopithecus africanus, was first published the museum's publication Kirtlandia (Johanson et al. 1978). Many other Ohioans became involved in this and other stories of paleoanthropological research.

There are countless stories I could tell, or that any other scientist could tell, about the circuitous routes that scientific careers take. Here is one more twist. Despite my many years of efforts at Taung, and at another fossil site in South Africa called 'Makapansgat,' I never found a single fossil of the ancestral creatures, called 'hominins', that led directly to our human species. I found lots of other cool fossils of extinct baboons and other mammalian creatures. My publications on these are still coming out, even as I write this letter.

By not finding a hominin fossil, I was led to think more about the importance of evolutionary context, and I have published a few papers about that. But I got to thinking about how that applies to today, and after some data base research, published a few more papers, which culminated in one of my books: Sparing Nature -- The Conflict Between Human Population Growth and Earth's Biodiversity (McKee 2003.) This led in turn to an invitation to speak in Washington, DC, to policy makers concerned with conservation. So there was this 'old bones' guy, giving advice to people from the United Nations, the World Health Organization, and a myriad of environmentalist groups. That was something I never envisioned as a young boy from Ohio, who just thought that fossils were cool.

A scientific career takes one to unexpected places, and leads one to unexplored thoughts. It is an adventure that has to be pursued with passion and perseverance, but has rewards, big and small, for both science and society. The beauty of youthful curiosity never fades.

Jeffrey K McKee is a Professor in the Department of Anthropology at The Obio State University, and is a co-editor of The Ohio Journal of Science. More information can be found at:

http://www.riddledchain.org/ 


\section{LITERATURE CITED}

Barbour, GB. 1949. Ape or Man? An Incomplete Chapter of Human Ancestry from South Africa. Ohio J. Sci. XLIX(4):129-145.

Dart,RA. 1925. Australopithecus africanus: The Man-Ape of South Africa. Nature 115: 195-199.

Darwin, C. 1871. The Descent of Man, and Selection in Relation to Sex. London, J. Murray.

Leakey, LSB.1953. Adam's Ancestors. New York, Harper \& Row.

Johanson DC.,White TD, Coppens,Y. 1978. A new species of the genus Australopithecus (Primates: Hominidae) from the Pliocene of Eastern AfricaKirtlandia 28:1-14.

McKee, JK. 2003. Sparing Nature - The Conflict between Human Population Growth an Earth's Biodiversity. Rutgers University

Press, Piscataway.

Bailey RM, Arnold LJ. 2006. Statistical modeling of single grain quartz De distributions and an assessment of procedures for estimating burial dose. Quat. Sci. Revs. 25:2475-2502.

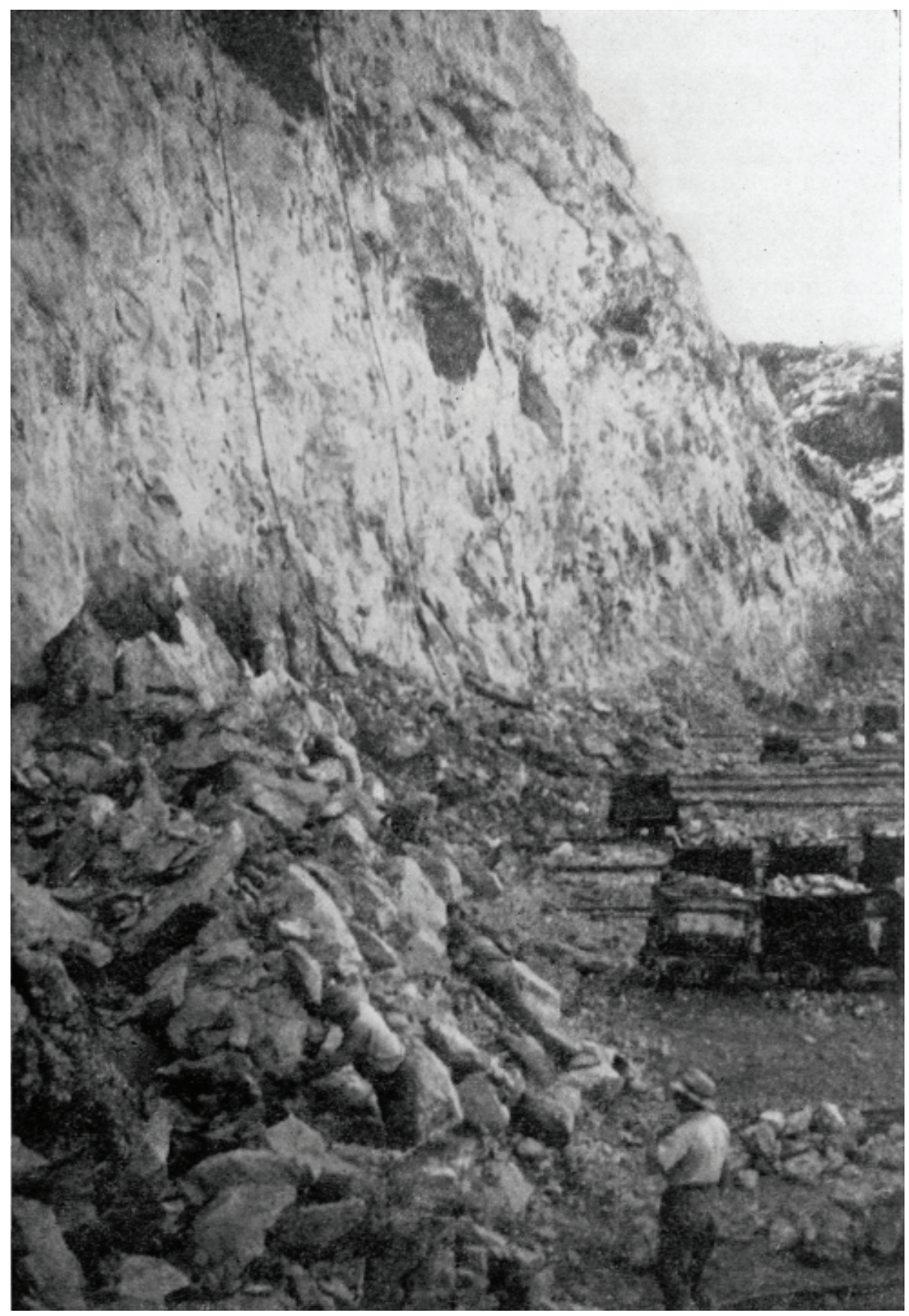

Figure 1 - Fossil hunting in blasted rocks at Taung’s site (reprinted from Barbour 1949) 


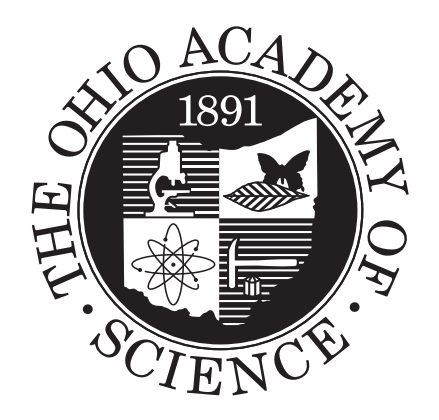

\section{The OHIO ACADEMy of SCIENCE provides STEM pathways to college and career readiness for Ohio's innovation economy.}

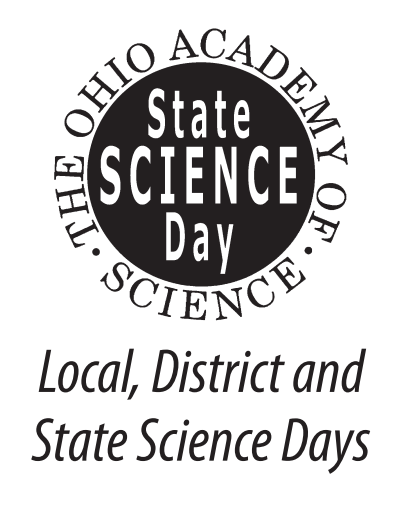

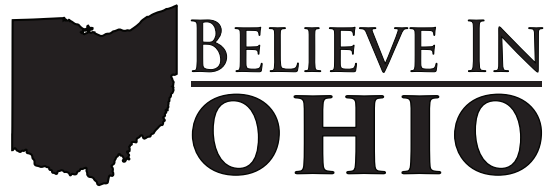

Curiosity • Discovery • Innovation ENTREPRENEURSHIP

Believe in Ohio Young STEM Entrepreneurship Program

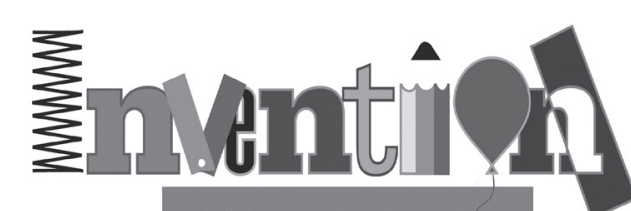

CONVENTIDN, Org

Invention Convention

www.ohiosci.org•614.488.2228•info@ohiosci.org

Fostering curiosity, discovery, innovation, and problem-solving skills in Obio 